\title{
SOSIALISASI PERATURAN PENGADAAN BARANG DAN JASA PEMERINTAH DALAM MENINGKATKAN SDM DESA LABANASEM, GINTANGAN, BARENG, BENELAN LOR DAN KARANG BENDO
}

\author{
M. Shofi'ul Amin, M. Toyib, Erna S., dan Wahyu Y. \\ Staf Pengajar, Politeknik Negeri Banyuwangi
}

\begin{abstract}
ABSTRAK
Seiring dengan kemajuan perkembangan mengenai pengembangan wilayah dan otonomi daerah, maka setiap daerah dituntut untuk mengembangkan wilayahnya termasuk desa/kelurahan. Hal ini berakibat pada pemanfaatan SDM secara mandiri. Menurut Kementerian Desa, Pembangunan Daerah Tertinggal dan Transmigrasi (Kemendes PDTT), untuk meningkatkan kesejahteraan dan pemerataan pembangunan, maka penggunaan dana desa harus diawasi dan dibina secara benar. Salah satu peran penting dalam mendorong percepatan pembangunan saat ini dibutuhkan pengawasan agar dana desa tidak diselewengkan melalui proses pengadaan barang/jasa pemerintah dengan baik dan benar. Mitra yang bekerjasama dalam kegiatan Ibm ini akan dilakukan bimbingan dan sosialisasi adalah desa yang memiliki tingkat pembangunan yang rendah di kawasan sekitar Politeknik Negeri Banyuwangi. Adapun Fokus sosialisasi adalah para perangkat desa disetiap desa/mitra yang sudah disurvey sebelumnya diantaranya Desa Labanasem, Gintangan, Bareng, Benelan Lor dan Karang Bendo. Pada laporan kemajuan pelaksanaan kegiatan ini, peserta total yang sudah dilakukan pelatihan sebanyak 66 orang, meliputi: 25 orang dari desa Labanasem, 10 orang dari Bareng, 11 orang dari Benelan Lor, 10 orang desa Gintangan dan 10 orang dari desa Karang Bendo. Setiap desa mitra mendapatkan sertifikat bagi pesertanya dan modul tentang tata cara pengadaan di Desa sesuai Peraturan Lembaga Kebijakan Pengadaan Barang/Jasa Pemerintah.
\end{abstract}

Kata kunci : IbM, sosialisasi, peraturan, pengadaan barang/jasa pemerintah

\section{PENDAHULUAN}

\begin{abstract}
Menurut Kementerian Desa Pembangunan Daerah Tertinggal dan Transmigrasi (Kemendes PDTT), untuk meningkatkan kesejahteraan dan pemerataan pembangunan, maka penggunaan dana desa harus diawasi dan dibina secara benar. Secara filosofi dana desa digunakan untuk meningkatkan pelayanan publik di desa, memajukan perekonomian, mengatasi kesenjangan pembangunan antar desa serta memperkuat masyarakat desa sebagai subyek pembangunan.

Salah satu peran penting dalam mendorong percepatan pembangunan saat ini dibutuhkan pengawasan agar dana desa tidak diselewengkan melalui proses pengadaan barang/jasa pemerintah dengan baik dan benar. Sehingga perangkat desa wajib mengerti dan memahami tentang peraturan Pengadaan Barang dan Jasa Pemerintah. Politeknik Negeri Banyuwangi memiliki tenaga-tenaga yang ahli dalam bidang pengadaan barang dan jasa pemerintah berkeinginan akan melakukan sosialisasi kepada jajaran perangkat desa. Lokasi desa yang akan dilakukan bimbingan dan sosialisasi adalah desa yang memiliki tingkat pembangunan yang rendah di kawasan sekitar Politeknik Negeri Banyuwangi.
\end{abstract}

Fokus sosialisasi adalah para perangkat desa disetiap desa/mitra yang sudah disurvey sebelumnya diantaranya Desa Labanasem, Gintangan, Bareng, Benelan Lor dan Karang Bendo. Permasalahan pada mitra yaitu minimnya pengetahuan perangkat desa tentang peraturan dan pengawasan pengadaan barang dan jasa pemerintah. Diharapkan dari kegiatan ini adalah perangkat desa mampu mengawasi setiap kegiatan pengadaan baik barang, fisik/infrastuktur dan jasa yang dilakukan oleh Pemerintah Daerah. Hal ini akan menjadikan perwujudan pembangunan yang baik, efisien dan pemanfaatan yang lebih besar kepada masyarakat.

\section{TARGET DAN LUARAN}

Sesuai target/luaran yang akan dihasilkan dalam pemecahan solusi diatas, maka spesifikasi luaran dari kegiatan ini adalah :

1. Perangkat desa mampu memahami tentang peraturan pengadaan barang dan jasa.

2. Perangkat desa mampu mengidentifikasi point-point penting dalam setiap pengawasan pengadaan barang dan jasa pemerintah.

3. Perangkat desa mampu mengidentifikasi permasalahan-permasalahan yang terjadi pada kegiatan pengadaan barang dan jasa. 
4. Terciptanya perangkat desa yang lebih produktif dalam pengawasan kegiatan pengadaan barang dan jasa.

\section{METODE PELAKSANAAN}

Solusi yang akan diberikan untuk mengatasi permasalah dengan melihat potret mitra dan himbauan menteri Desa, maka dalam penerapan iptek ini akan dilakukan serangkaian kegiatan bimbingan, sosialisasi, dan pembagian pedoman terbaru tentang pengadaan barang dan jasa pemerintah. Adapun secara umum pada kegiatan ini meliputi 4 aspek yaitu :

1. Sosialisasi/pengenalan tentang peraturan terbaru perihal Pengadaan Barang dan Jasa Pemerintah dan Perubahannya sesuai PERPRES Nomor 4 Tahun 2015 dan PERKA LKPP Nomor 13 Tahun 2013 serta perubahannya Nomor 22 Tahun 2015 tentang pengadaan barang/jasa di desa.

2. Pembahasan tentang point-point penting dalam setiap pengawasan pengadaan barang dan jasa pemerintah.

3. Penyuluhan/seminar dan pembagian pedoman tentang permasalahanpermasalahan yang terjadi pada kegiatan pengadaan barang dan jasa.

\section{HASIL DAN PEMBAHASAN}

\section{Sosialisasi Pengadaan di Desa Labanasem}

Pelaksanaan kegiatan dilakukan pada desa terdekat dari kampus yaitu desa Labanasem kecamatan Kabat. Sebelum dilakukan sosialisasi, maka tim pengabdi akan melakukan pengaturan jadwal dengan perangkat desa tentang pelaksanaan kegiatan tersebut. Waktu pelaksanaan sosialisasi di desa labanasem dilaksanakan pada hari selasa tanggal 18 Oktober 2016 bertempat di Pendopo Desa Labanasem. Jumlah peserta keseluruhan adalah 25 orang. Adapun dokumentasi kegiatan adalah sebagai berikut :

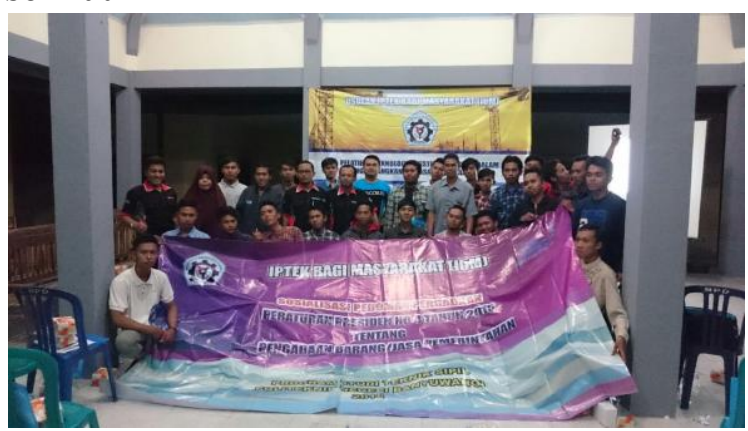

Gambar 1 Sosialisasi di Desa Labanasem

\section{Sosialisasi Pengadaan di Desa Bareng}

Waktu pelaksanaan sosialisasi di desa Bareng dilaksanakan pada hari jumat tanggal 4 November 2016 bertempat di Pendopo Desa Bareng Kecamatan Kabat. Jumlah peserta keseluruhan adalah 10 orang. Peserta sosialisasi adalah perangkat desa dan sebagian para pemuda karang taruna. Adapun dokumentasi kegiatan adalah sebagai berikut:

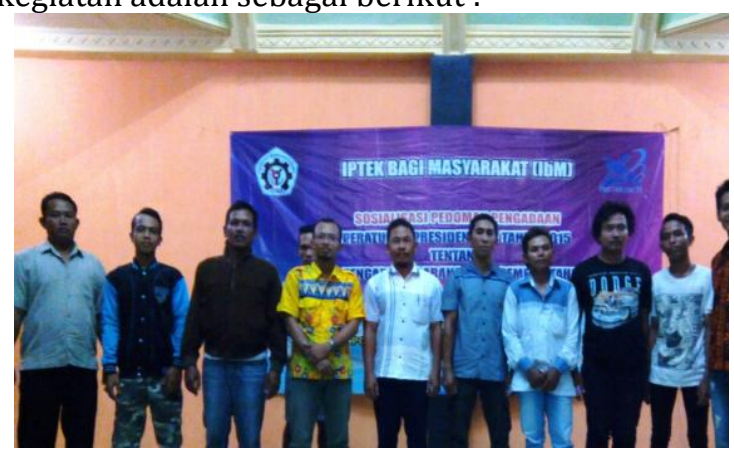

Gambar 2 Sosialisasi di Desa Bareng

\section{Sosialisasi Pengadaan di Desa Karang Bendo}

Waktu pelaksanaan sosialisasi di desa Karang Bendo, Benelan Lor dan Gintangan dilaksanakan masing-masing pada tanggal 8 November 2016 bertempat di ruang rapat desa. Jumlah peserta keseluruhan desa tersebut adalah 10 orang. Peserta sosialisasi keseluruhan terdiri dari unsur perangkat desa. Adapun dokumentasi kegiatan adalah sebagai berikut:

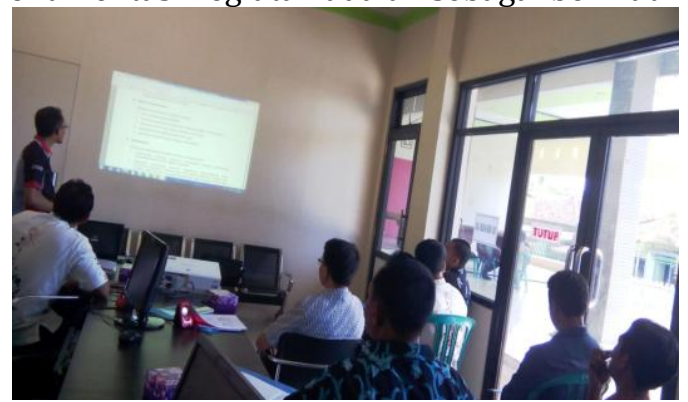

Gambar 3 Sosialisasi di Desa Karang Bendo

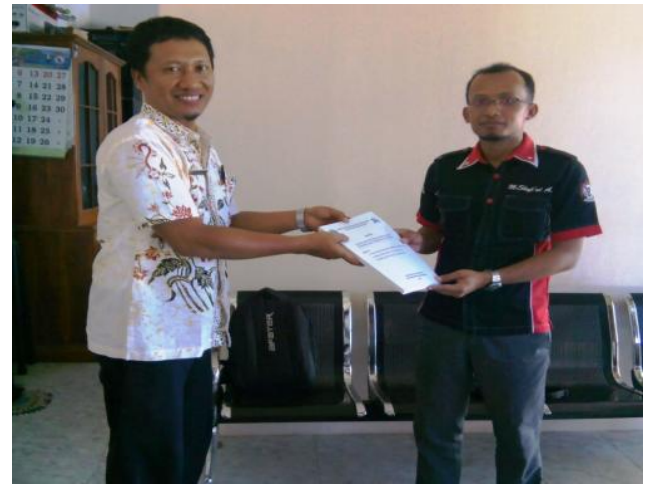

Gambar 4 Penyerahan secara Simbolis Modul Peraturan Pengadaan 


\section{Sosialisasi Pengadaan di Desa Benelan Lor} Waktu pelaksanaan sosialisasi di desa Benelan Lor, dilaksanakan pada tanggal 24 November 2016 bertempat di ruang rapat desa. Jumlah peserta keseluruhan desa tersebut adalah 11 orang. Peserta sosialisasi keseluruhan terdiri dari unsur perangkat desa, perwakilan LPMD dan anggota tim TPK (Tim Pengelola Kegiatan). Adapun dokumentasi kegiatan adalah sebagai berikut :

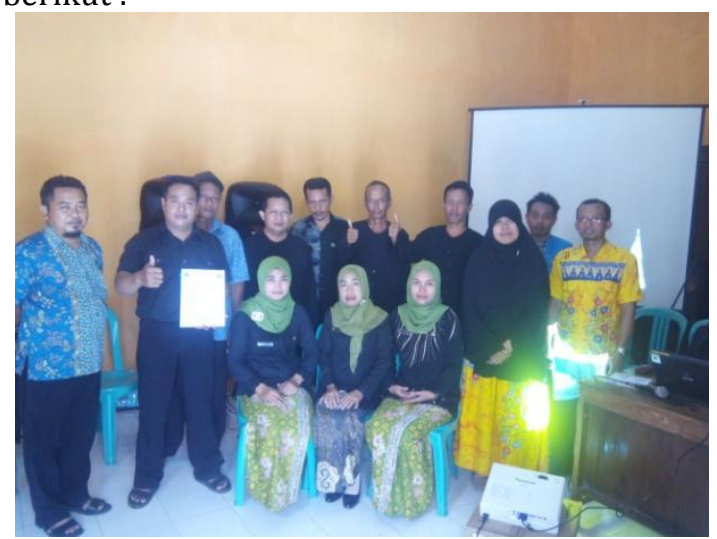

Gambar 5 Sosialisasi di Desa Benelan Lor Sosialisasi Pengadaan di Desa Gintangan

Waktu pelaksanaan sosialisasi di desa Gintangan, dilaksanakan pada tanggal 28 November 2016 bertempat di ruang rapat desa. Jumlah peserta keseluruhan desa tersebut adalah 10 orang. Peserta sosialisasi keseluruhan terdiri dari unsur perangkat desa, dan anggota tim TPK (Tim Pengelola Kegiatan) serta 1 kepala desa. Adapun dokumentasi kegiatan adalah sebagai berikut :

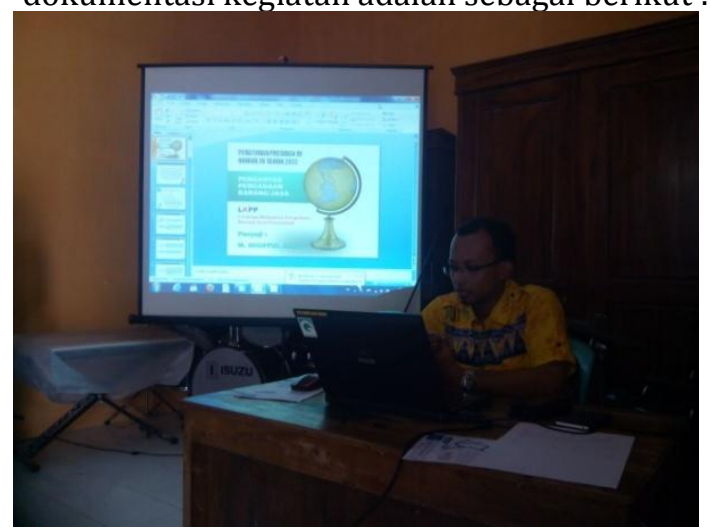

Gambar 3.3 Sosialisasi di Desa Gintangan

Seluruh peserta dalam kegiatan ini telah dibagikan materi tentang pengadaan secara umum dan pada setiap desanya akan dibagikan modul panduan dan peraturan tata cara pengadaan. Selain itu peserta juga diberikan sertifikat sebagai peserta pelatihan.

\section{KESIMPULAN DAN SARAN}

Pelaksanaan kegiatan yang sudah dilaksanakan secara garis besar dapat disimpulkan sebagai berikut :

1. Peserta total yang sudah dilakukan pelatihan sebanyak 66 orang, meliputi: 25 orang dari desa Labanasem, 10 orang dari Bareng 10 orang dari desa Karang Bendo, 11 orang dari desa Benelan Lor dan 10 orang dari desa Gintangan.

2. Setiap desa mitra mendapatkan sertifikat bagi pesertanya dan modul tentang tata cara pengadaan di Desa sesuai Peraturan Lembaga Kebijakan Pengadaan Barang/Jasa Pemerintah.

Sedangkan saran untuk pelaksanaan kegiatan ini adalah :

1. Kegiatan dilakukan dengan contoh pelaksanaan kondisi eksisting di masingmasing desa mitra

2. Acara dilakukan secara berkala dan berkelanjutan.

\section{DAFTAR PUSTAKA}

[1] Peraturan Presiden Republik Indonesia Nomor 4 Tahun 2015 "Tentang Perubahan Keempat Atas Peraturan Presiden Nomor 54 Tahun 2010 Tentang Pengadaan Barang/Jasa Pemerintah".

[2] Peraturan Kepala LKPP Nomor 13 Tahun 2013 "Tentang Pedoman Tata Cara Pengadaan Barang/Jasa di Desa".

[3] Peraturan Kepala LKPP Nomor 22 Tahun 2015 “Tentang Perubahan Atas Peraturan Kepala LKPP Nomor 13 Tahun 2013 Tentang Pedoman Tata Cara Pengadaan Barang/Jasa di Desa".

[4] Web Resmi. Kementerian Desa, Pembangunan Daerah Tertinggal dan Transmigrasi. www.kemendesa.go.id 